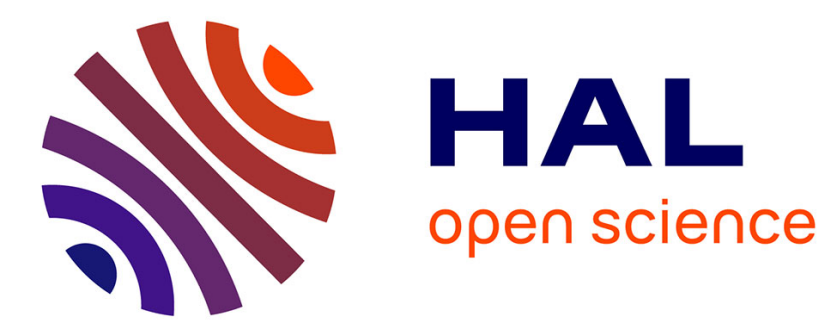

\title{
Virtual crystal approximation study of nitridosilicates and oxonitridoaluminosilicates
}

\author{
Dan J Wilson, B. Björn Winkler, Erick A Juarez-Arellano, Alexandra \\ Friedrich, Karsten Knorr, Chris J Pickard, Victor Milman
}

\section{- To cite this version:}

Dan J Wilson, B. Björn Winkler, Erick A Juarez-Arellano, Alexandra Friedrich, Karsten Knorr, et al.. Virtual crystal approximation study of nitridosilicates and oxonitridoaluminosilicates. Journal of Physics and Chemistry of Solids, 2009, 69 (7), pp.1861. 10.1016/j.jpcs.2008.01.009 . hal-00531145

\author{
HAL Id: hal-00531145 \\ https://hal.science/hal-00531145
}

Submitted on 2 Nov 2010

HAL is a multi-disciplinary open access archive for the deposit and dissemination of scientific research documents, whether they are published or not. The documents may come from teaching and research institutions in France or abroad, or from public or private research centers.
L'archive ouverte pluridisciplinaire HAL, est destinée au dépôt et à la diffusion de documents scientifiques de niveau recherche, publiés ou non, émanant des établissements d'enseignement et de recherche français ou étrangers, des laboratoires publics ou privés. 


\section{Author's Accepted Manuscript}

Virtual crystal approximation study of nitridosilicates and oxonitridoaluminosilicates

Dan JWilson, Björn Winkler, ErickA Juarez-Arellano, Alexandra Friedrich, Karsten Knorr, Chris J Pickard, Victor Milman

PII: S0022-3697(08)00026-7

DOI: $\quad$ doi:10.1016/j.jpcs.2008.01.009

Reference: $\quad$ PCS 5365

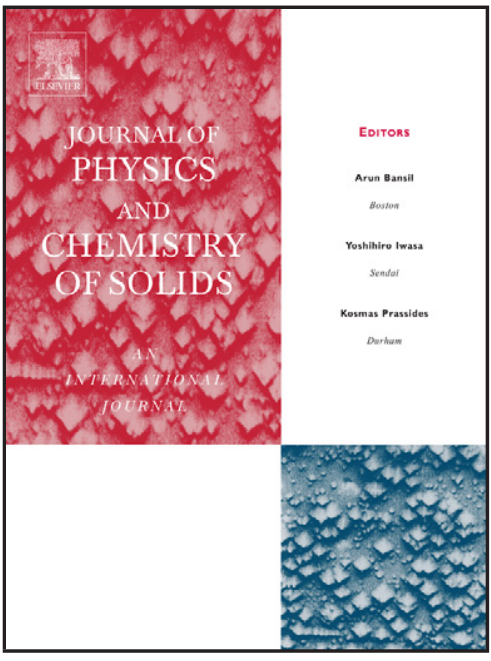

www.elsevier.com/locate/jpcs

To appear in: Journal of Physics and

Chemistry of Solids

Received date: $\quad 3$ May 2007

Revised date: $\quad 14$ January 2008

Accepted date: 15 January 2008

Cite this article as: Dan J Wilson, Björn Winkler, Erick A Juarez-Arellano, Alexandra Friedrich, Karsten Knorr, Chris J Pickard and Victor Milman, Virtual crystal approximation study of nitridosilicates and oxonitridoaluminosilicates, Journal of Physics and Chemistry of Solids (2008), doi:10.1016/j.jpcs.2008.01.009

This is a PDF file of an unedited manuscript that has been accepted for publication. As a service to our customers we are providing this early version of the manuscript. The manuscript will undergo copyediting, typesetting, and review of the resulting galley proof before it is published in its final citable form. Please note that during the production process errors may be discovered which could affect the content, and all legal disclaimers that apply to the journal pertain. 


\title{
Virtual crystal approximation study of nitridosilicates and oxonitridoaluminosilicates
}

\author{
Dan J Wilson, ${ }^{\mathrm{a},}$, Björn Winkler ${ }^{\mathrm{a}}$, Erick A Juarez-Arellano ${ }^{\mathrm{a}}$, Alexandra Friedrich ${ }^{\mathrm{a}}$, \\ Karsten Knorr ${ }^{\mathrm{b}}$, Chris J Pickard ${ }^{\mathrm{c}}$, Victor Milman ${ }^{\mathrm{d}}$ \\ ${ }^{a}$ Institut für Geowissenschaften, Abt. Kristallographie, Johann Wolfgang Goethe-Universität Frankfurt, \\ Altenhöferallee 1, D-60438 ${ }^{1}$ Frankfurt am Main, Germany \\ ${ }^{b}$ Institut für Geowissenschaften, Mineralogie, Kristallographie, Christian-Albrechts-Universität zu Kiel, \\ Olshausenstraße 40, D-24098 Kiel, Germany \\ ${ }^{c}$ School of Physics \& Astronomy, University of St. Andrews, North Haugh, St. Andrews KY16 9SS, UK \\ ${ }^{d}$ Accelrys Inc., 334 Cambridge Science Park, Cambridge CB4 OWN, UK
}

\begin{abstract}
We present a density functional theory study of a variety of nitridosilicate and oxonitridoaluminosilicate systems. For the nitridosilicates, we have shown that the DFT-calculated equilibrium structures of BaYb$\mathrm{Si}_{4} \mathrm{~N}_{7}, \mathrm{SrYb}-\mathrm{Si}_{4} \mathrm{~N}_{7}$ and EuYb-Si $\mathrm{N}_{4}$ are in good agreement with experiment. We then used the virtual crystal approximation (VCA) to study the effects of oxygen-doping on the nitrogen sites. We then added $\mathrm{Si} / \mathrm{Al}$ disorder into our system, in order to model the properties of $\mathrm{BaYb} \mathrm{SiAlON}$ for pressures up to 50 $\mathrm{GPa}$, in order to investigate recent experimental findings. We have found that this system is stable over the whole pressure range, and that the compression mechanism is pure bond length shortening.
\end{abstract}

Keywords: A. Inorganic compounds; C. Ab initio calculations; D. Equations-of-state

\section{Introduction}

The nitridosilicates and oxonitridoaluminosilicates are of technological interest due to their high mechanical hardness and strength, their thermal and chemical stability, and their relatively low density [1]. The characteristic building blocks in the nitridosilicates are $\mathrm{SiN}_{4}$-tetrahedra, which readily form a three-dimensional tetrahedral network by sharing corners [1]. In contrast to oxosilicates, where oxygen atoms are either terminally bound to silicon, or connect two tetrahedrally- or octahedrally-coordinated $\mathrm{Si}$ atoms, nitrogen atoms can be shared by two, three or even four $\mathrm{SiN}_{4}$-tetrahedra. Throughout this work, nitrogen atoms shared by two, three or four $\mathrm{SiN}_{4}$-tetrahedra are denoted $\mathrm{N}^{[2]}, \mathrm{N}^{[3]}$ and $\mathrm{N}^{[4]}$, respectively. Of the nitridosilicates synthesized so far, $\mathrm{BaYb}$

\footnotetext{
*Corresponding author. Tel+496979840111. E-mail address: wilson@kristall.uni-frankfurt.de
} 
$\mathrm{Si}_{4} \mathrm{~N}_{7}$ is particularly interesting, as it was the first nitridosilicate that was found to contain both $\mathrm{N}^{[2]}$ and $\mathrm{N}^{[4]}$ atoms [2]. Furthermore, it represents the aristotype of several substitutional derivatives $\mathrm{MYb} \mathrm{Si}_{4} \mathrm{~N}_{7}[3,4]$.

The synthesis of the nitridosilicates is experimentally demanding, as the presence of oxygen has to be excluded. Furthermore, it is challenging to detect the incorporation of small amounts of oxygen by chemical analysis of the products, and little is known about the influence that small amounts of oxygen can have on structural and physical properties. Specifically, magnetic investigations may be difficult to interpret, as oxygen impurities would lead to a partial reduction of the magnetic moments per formula unit, but these could also be due to the presence of vacancies in the anion sub-lattice [5]. The magnetic properties of $\mathrm{MYb} \mathrm{Si}_{4} \mathrm{~N}_{7}$, with $\mathrm{M}=\mathrm{Sr}, \mathrm{Ba}, \mathrm{Eu}$, have recently been investigated experimentally [5]. In these measurements, a significant decrease of the magnetic moment of the $\mathrm{Yb}$-ion with respect to its free ion value has been observed.

A combined partial substitution of Si by $\mathrm{Al}$ and $\mathrm{N}$ by $\mathrm{O}$ leads to the oxonitridoaluminosilicates ("SiAlONs") [6]. This coupled substitution is difficult to quantify, but has influence on the properties of this system. A specific problem during the investigation of SiAlONs is to establish if the $\mathrm{Si}^{4+} / \mathrm{Al}^{3+}$ and $\mathrm{O}^{2-} / \mathrm{N}^{3-}$ atoms are crystallographically ordered. The very similar X-ray atomic scattering factors of $\mathrm{Si}^{4+} / \mathrm{Al}^{3+}$ and $\mathrm{O}^{2-} / \mathrm{N}^{3-}$ preclude direct determination of site occupancies from X-ray diffraction data, so neutron diffraction experiments have to be performed. Unfortunately, the $\mathrm{Si} / \mathrm{Al}$ and $\mathrm{O} / \mathrm{N}$ occupancies have only been determined experimentally for a few $\mathrm{SiAlON}$ structures, such as $\mathrm{Sr}_{3} \operatorname{Pr}_{10} \mathrm{Si}_{18} \mathrm{Al}_{12} \mathrm{O}_{18} \mathrm{~N}_{36}$ [6] and $\mathrm{Nd}_{2} \mathrm{Si}_{2.5} \mathrm{Al}_{0.5} \mathrm{O}_{3.5} \mathrm{~N}_{3.5}[7]$.

In addition to the order/disorder question, there is also uncertainty concerning the high pressure behaviour of the $\mathrm{BaYb}$ SiAlONs. Recently, we have investigated the $\mathrm{BaYb}$ $\mathrm{Si}_{2} \mathrm{Al}_{2} \mathrm{O}_{2} \mathrm{~N}_{5}$ system by in situ high-pressure powder X-ray diffraction at pressures of up to $37 \mathrm{GPa}$ using the diamond-anvil cell technique [8]. However, due to inherent restrictions related to in situ high-pressure powder X-ray diffraction, it was not possible to determine the compression mechanism. Furthermore, from the $f-F$ Eulerian strain versus normalized stress plots, the linear behaviour of the experimental data became strongly non-linear at Eulerian strain values which correspond to pressures higher than 
$30 \mathrm{GPa}$. This deviation from the low-pressure behaviour could be indicative of an approach to the limit of phase stability. Whether this non-linearity is real was one of the issues we wanted to answer with this study.

Density functional theory (DFT) based calculations are well established in the study of structure-property relations of solids [9]. Furthermore, it has been demonstrated that DFT is capable of reproducing the effects of the lanthanide and actinide elements present in the materials studied here [10,11]. The virtual crystal approximation (VCA) can, at least in principle, be used to investigate and predict the effect of doping and of disorder, and has already proven accurate for studies of $\mathrm{Si} / \mathrm{Al}$ order/disorder $[12,13]$ and for solid solutions of perovskites [14].

In Section 3.1, after investigating the structures of the pure $\mathrm{MYb} \mathrm{Si}_{4} \mathrm{~N}_{7}(\mathrm{M}=\mathrm{Ba}, \mathrm{Sr}$, $\mathrm{Eu})$ systems, we employ the VCA technique to study the effects of small amounts of oxygen on the crystal structure of $\mathrm{BaYb} \mathrm{Si}_{4} \mathrm{~N}_{7}$ : a typical nitridosilicate. In Section 3.2, we extend this study to the simulation of a typical SiAlON system. In order to investigate our recent experimental findings described above, we have calculated the structures of $\mathrm{BaYb} \mathrm{Si}_{2} \mathrm{Al}_{2} \mathrm{O}_{2} \mathrm{~N}_{5}$ at simulated pressures in the range $0-50 \mathrm{GPa}$. To our knowledge, this is the first time that the VCA technique has been used for a system containing coupled disorder.

\section{Computational details}

The quantum mechanical calculations described here are based on density functional theory and the PBE-version of the generalized gradient approximation (GGA) [15], adapted for spin-density calculations. Ultrasoft pseudopotentials were used with a plane wave basis set, truncated at a kinetic energy of $500 \mathrm{eV}$. In addition to this cut-off energy, one further parameter determines the quality of the calculations, namely the density of points with which the Brillouin zone is sampled. The wave vectors for the sampling points were chosen according to the scheme proposed by Monkhorst and Pack [16]. Here, we use a sampling of reciprocal space such that distance between grid points is about $0.03 \AA^{-1}$. Full geometry optimization calculations were performed in which all structural parameters not constrained by the space group symmetry ( $\left.\mathrm{P} 6_{3} \mathrm{mc}\right)$ were relaxed. After the final self-consistency cycle, the remaining forces on the atoms were less than $0.01 \mathrm{eV} / \AA$, and the remaining stress was less than $0.05 \mathrm{GPa}$. The present 
calculations are restricted to the athermal limit, in which temperature effects and zeropoint motions are neglected. For all calculations we used both the academic and commercial versions of the CASTEP program, which has been described elsewhere $[9,17]$.

The VCA calculations are based on a weighting of the contribution of the pseudopotentials according to the site occupancies [14]. This VCA approach could, in principle, be used to study any composition in a solid solution. However, the number of electrons in the unit cell changes when a nitrogen ion is partially replaced by an oxygen ion. In the general case, this leads to a non-integer number of electrons in the unit cell. A treatment of this condition would require major modifications to $\mathrm{CASTEP}^{2}$, and hence the current study was restricted to those compositions with an integer number of electrons.

For our study of oxygen doping, we have investigated the possible incorporation of oxygen on the three available nitrogen sites. The smallest possible unit cell for the undoped Ba-containing end-member is $\mathrm{Ba}_{2} \mathrm{Yb}_{2} \mathrm{Si}_{8} \mathrm{~N}_{14}$. To clarify the different coordinations, this is better written as $\mathrm{Ba}_{2} \mathrm{Yb}_{2} \mathrm{Si}_{8} \mathrm{~N}(1){ }_{2}^{[4]} \mathrm{N}(2){ }_{6}^{[2]} \mathrm{N}(3){ }_{6}^{[2]}$. Here, the values in parentheses are consecutive labels for nitrogen atoms occupying different Wyckoff sites $(\mathrm{N}(1)$ is located on Wyckoff position $2 \mathrm{~b}$ with $00 \mathrm{z}, \mathrm{N}(2)$ and $\mathrm{N}(3)$ are on Wyckoff position 6c-see figure 1). For the smallest possible oxygen concentrations, the constraint of having an integer number of electrons then leads to a composition of $\mathrm{Ba}_{2} \mathrm{Yb}_{2} \mathrm{Si}_{8} \mathrm{~N}_{13} \mathrm{O}$, if the unit cell size is unchanged. The oxygen could either be incorporated by a VCA model for N(1), N(2) or N(3). For the two substitutions on N(2) and $\mathrm{N}(3)$, i.e. on Wyckoff position 6c, this corresponds to an $\mathrm{N}$ :O ratio of 83.33:16.67 on that site. For the N(1) site, the ratio would be $50: 50$.

[Fig 1 around here]

To obtain smaller concentrations, the unit cell can be doubled, such that the unit cell then contains $\mathrm{Ba}_{4} \mathrm{Yb}_{4} \mathrm{Si}_{16} \mathrm{~N}_{27} \mathrm{O}$. For the substitution on $\mathrm{N}(2)$ and $\mathrm{N}(3)$ the on-site $\mathrm{N}: \mathrm{O}$ ratio is then 91.67:8.33, while for the $\mathrm{N}(1)$ site it still would be a high value of 75:25.

\footnotetext{
${ }^{2}$ During the preparation of this manuscript, we became aware that the recently-released CASTEP 4.1 includes these modifications.
} 
To investigate the influence of a more realistic N(1) concentration, an additional calculation for a unit cell with a volume of $1264 \AA^{3}$ containing $\mathrm{Ba}_{8} \mathrm{Yb}_{8} \mathrm{Si}_{32} \mathrm{~N}_{55} \mathrm{O}$ was performed.

For our study of the double-substituted BaYb SiAlONs, we have introduced Si/Aldisorder (50:50) in addition to $\mathrm{O} / \mathrm{N}$ disorder across the $\mathrm{N}(2)$ and $\mathrm{N}(3)$ sites (33.3:66.7), resulting in the experimentally-determined stoichiometry $\mathrm{BaYb} \mathrm{Si}_{2} \mathrm{Al}_{2} \mathrm{O}_{2} \mathrm{~N}_{5}$. Although other proportions can lead to the same stoichiometry, these values were considered more realistic, based on the results in Section 3.1.

\section{Results}

\subsection{Nitridosilicates}

The results of the full geometry optimization of $\mathrm{BaYb} \mathrm{Si}_{4} \mathrm{~N}_{7}, \mathrm{SrYb} \mathrm{Si}_{4} \mathrm{~N}_{7}$, and $\mathrm{EuYb}$ $\mathrm{Si}_{4} \mathrm{~N}_{7}$ are given in table 1. It is clear that in all cases the computed structural parameters agree with the corresponding experimental values to within the accuracy usually obtained in DFT-based calculations [9]. It is worthwhile to note that the relative lengths of the cell parameters $\left(a_{\mathrm{EuYb}}<a_{\mathrm{SrYb}}<a_{\mathrm{BaYb}}\right)$ and the constant $a / c$-ratio are reproduced, which convincingly demonstrates the relative accuracy of the calculations.

[Table 1 around here]

All calculations were performed using a spin-polarised exchange-correlation functional. The energy differences between spin-polarised and non spin-polarised ground states were found to be rather small. For example, in $\mathrm{BaYb}_{-} \mathrm{Si}_{4} \mathrm{~N}_{7}$ the spin-polarised ground state with a total spin density of $1 \mathrm{~h}$ is only $0.2 \mathrm{eV}$ per unit cell more stable than the unpolarised structure. The change of the spin state does not seem to affect the structural parameters significantly in the present cases. The spin at the $\mathrm{Yb}$ ion was 0.36 $\hbar$ for $\mathrm{SrYb} \mathrm{Si}_{4} \mathrm{~N}_{7}, 0.39 \hbar$ for $\mathrm{BaYb} \mathrm{Si}_{4} \mathrm{~N}_{7}$ and $0.47 \hbar$ for $\mathrm{EuYb} \mathrm{Si}_{4} \mathrm{~N}_{7}$, in agreement with the value that would be expected for the $\mathrm{Yb}^{3+}$. For the europium ions the spin is $3.0 \mathrm{~h}$. As the integrated spin density in $\mathrm{EuYb} \mathrm{Si}_{4} \mathrm{~N}_{7}$ is $7.5 \mathrm{~h}$, and as there are two $\mathrm{Yb}$ and two Eu ions in the unit cell, there is some itinerant magnetism.

We have found that incorporation onto $\mathrm{N}(2)$ is slightly preferred $\left(\Delta \mathrm{E} \sim-5.8 \mathrm{kJmol}^{-1}\right)$ to the incorporation on $\mathrm{N}(3)$ at the lower concentration (27:1), but the situation is reversed 
at the higher concentration $(13: 1)\left(\Delta \mathrm{E} \sim 12.6 \mathrm{kJmol}^{-1}\right)$. As these numbers are very small, we will assume that in a realistic system, the doped oxygen is spread equally over the two sites $\mathrm{N}(2)$ and $\mathrm{N}(3)$ (see Section 3.2).

Similar comparisons with the N(1) site are not possible, as the total energies from the VCA calculations are dependent upon the site-occupancies, which differ between N(1) and $\mathrm{N}(2) / \mathrm{N}(3)$. However, previous neutron diffraction experiments and Monte Carlo simulations have shown that incorporation at the N(1) site is not likely as this would involve 4-coordinated oxygen [18].

[Table 2 around here]

The unit cell volume does not change significantly when $\sim 10 \%$ of the nitrogen is replaced, as the relaxed structure of $\mathrm{BaYbSi}_{4} \mathrm{~N}_{7}$ has a unit cell volume of $316.2 \AA^{3}$, while the VCA model gives $315.9 \AA^{3}$ and $316.0 \AA^{3}$ for the $N(2)$ and N(3) sites respectively. The doping has a noticeable effect on the spin density, as the spin on the $\mathrm{Yb}$-ions decreases on doping by about a third to $0.25 \mathrm{~h}$, while the total spin density drops to $0.5 \mathrm{~h}$. This strengthens the arguments brought forward to explain the significant decrease by $\sim 35 \%$ of the experimentally observed magnetic moments with respect to the free ion value [5], although the quantitative agreement is probably fortuitous.

\subsection{BaYb-SiAlON}

While in the nitridosilicates, special attention was paid to the anion sites $\left(\mathrm{N}^{[4]}(1)\right.$, $\mathrm{N}^{[2]}(2)$ and $\mathrm{N}^{[2]}(3)$ ), in BaYb-SiAlON the tetrahedral cation sites also have to be considered, which we will call $\mathrm{T}(1)$ and $\mathrm{T}(2)$. T(1) is located on Wyckoff position $2 b$ with $00 z$ and $T(2)$ is on Wyckoff position $6 c$, as shown in figure 3.

[ Fig 2 around here]

The calculated $\mathrm{BaYb}$ SiAlON structures at 0,30 and $50 \mathrm{GPa}$, and the bonds lengths and angles, are summarized in tables 3 and 4, respectively. From table 3 it is clear that the computed structural parameters in $\mathrm{BaYb} \mathrm{SiAlON}$ at $0 \mathrm{GPa}$ agree well with the 
corresponding experimental values obtained by powder x-ray diffraction [19]. The theoretical lattice parameters and the atomic position values deviate from the experimental data by less than $0.62 \%$ and $0.48 \%$, respectively. The computed bond lengths and angles are in good agreement with the experimental values (table 4).

[Tables $3+4$ around here]

In $\mathrm{BaYb}$ SiAlON, the results of the calculations suggest that the $\mathrm{T}(1)$ and $\mathrm{T}(2)$ sites are occupied in equal parts by Si and Al. The $\mathrm{N}^{[2]}(2)$ and $\mathrm{N}^{[2]}(3)$ sites have a N:O ratio of $2 / 3: 1 / 3$, while $\mathrm{N}^{[4]}(1)$ is fully occupied by $\mathrm{N}$ (based on the results of the previous section). Again very good agreement with the experimental results is observed [19].

The [T(1)-T(2)]- $\mathrm{N}^{[2]}$ bond length (1.759 $\AA$ average value) is shorter than [T(1)-T(2)]$\mathrm{N}^{[4]}(1.896 \AA$ average value). If the values of $0.325,1.42$ and $1.46 \AA$ are used as the ionic radii of $\mathrm{Si}^{4+} / \mathrm{Al}^{3+}, \mathrm{O}^{2-} / \mathrm{N}^{3-}$ and $\mathrm{N}^{3-}$, respectively [20], the [T(1)- $\left.\mathrm{T}(2)\right]-\mathrm{N}^{[2]}$ distances agree with the sum of the corresponding ionic radii $(1.745 \AA)$. The $[\mathrm{T}(1)-\mathrm{T}(2)]-\mathrm{N}^{[4]}$ average value is higher than the sum of the corresponding ionic radii, due to the increased coordination of the nitrogen ion from $\mathrm{N}^{[2]}$ to $\mathrm{N}^{[4]}$. This phenomenon is present in all the isotypic nitridosilicate and SiAlON compounds [3, 4, 19, 21].

\subsubsection{Bulk and linear compressibility.}

The dependence of the theoretical volume as a function of pressure is plotted in figure 4. From a fit of a third-order Birch-Murnaghan equation of state (EOS) to the calculated $p$ - $V$ data up to $50 \mathrm{GPa}$ using the program EOS-FIT [22] we have obtained the isothermal bulk modulus, $B_{0}$, and the first pressure derivative of the bulk modulus, $B^{\prime}$; the results are shown in table 5 . From the table, it can be seen that the theoretical values are systematically smaller than the experimental values. However, the errors in $B_{0}$ are smaller than $10 \%$, which is typical for GGA DFT calculations [23].

[Fig 3 around here]

[Table 5 around here] 
In order to make complex trends visible which are not directly apparent from a $p-V$ plot, the data were transformed into normalized pressure, F, and Eulerian strain, $f$ [24]. For a Birch-Murnaghan EOS the Eulerian strain is given by $f=1 / 2\left[\left(V_{0} / V\right)^{2 / 3}-1\right]$ and the normalized stress is defined as $F=P /\left[3 f(1+2 f)^{5 / 2}\right]$. The $f$-F plot gives a direct indication of the compression behaviour. The $f-F$ plot of both the theoretical and the experimental data is shown in Figure 5. From Figure 5, while the linear behaviour of the experimental data becomes strongly non-linear at Eulerian strain values higher than around 0.045 , which correspond to pressures higher than $30 \mathrm{GPa}$, the calculated data shows linearity over the whole interval. As the lack of a pressure-induced phase transition could be due to the symmetry imposed on these calculations, we repeated the highest-pressure calculation $(50 \mathrm{GPa})$ with the symmetry reduced to P1. However, this calculation resulted in the same structure as our $\mathrm{P}_{3} \mathrm{mc}$ calculation. Therefore, the VCA calculations give no evidence for a pressure-induced structural phase transformation due to elastic instabilities in BaYb SiAlON, and the unusual stability at high pressures reported experimentally by Juarez-Arellano et al. [8] is confirmed.

[Fig 4 around here]

Although a difference between the theoretical and experimental $f-F$ plot is clearly seen in figure 5, the shift is a direct consequence of the different values of the predicted and experimental bulk moduli. The slope of the plots is approximately the same, as can be confirmed by comparing the first pressure derivative values ( 4.3 and 4.7 for theory and experiment, respectively).

The dependence of the theoretical cell parameters as a function of pressure is plotted in figure 6 . The $p-a$ and $p-c$ theoretical data were fitted with a third-order BirchMurnaghan EOS. The resulting parameters are summarized in table 5. Unlike in the experimental data, the DFT calculations suggest that the compressibility is smaller in the $a$-direction than in the $c$-direction. However, the difference between the two values is small, $4 \mathrm{GPa}$, and is likely to be below the resolution of these calculations. We therefore believe that the compressibility is approximately isotropic, in agreement with experimental data. 
[Figs $5 \mathrm{a}+\mathrm{b}$ around here]

The variation in the polyhedral angles between the VCA results at 0 and $50 \mathrm{GPa}$ (table 4 ) is less than $1 \%$. This implies that the tetrahedral network (figure 3 ) is so stiff that a homogeneous bond length compression is the only pressure effect. These results confirm the high pressure stability of the crystal structure of BaYb SiAlON, and pure bond length compression has been identified as the compression mechanism.

\section{Conclusions}

We have shown here that the VCA approach is useful for modelling both sitedependent $\mathrm{O}^{2-} / \mathrm{N}^{3-}$ disorder, and coupled $\mathrm{Si}^{4+} / \mathrm{Al}^{3+}$ and $\mathrm{O}^{2-} / \mathrm{N}^{3-}$ disorder. We have shown that when a nitridosilcate is oxygen-doped, the oxygen tends to substitute for nitrogen on the $\mathrm{N}(2)$ and $\mathrm{N}(3)$ sites. The behaviour of the BaYb SiAlON crystal structure at high pressure was calculated, and the results are in good agreement with the experimental results. Pure bond length compression was identified as the compression mechanism. The VCA results give no evidence for a pressure-induced structural phase transformation and confirm the unusual stability of $\mathrm{BaYb}$ SiAlON at pressures up to 50 GPa.

\section{Acknowledgements}

The authors gratefully acknowledge financial support from the Deutsche Forschungsgemeinschaft (DFG) (Grants WI 1232/17-1, WI 1232/17-2) within the project SPP-1136. One of the authors (E. A. Juarez-Arellano) acknowledges D. Argott de Juarez for all help given. D. Wilson would like to thank the MaterialsGrid project (http://www.materialsgrid.org) for funding.

\section{References}

[1] W. Schnick, H. Huppertz and R. Lauterbach, J. Mat. Chem. 9 (1999), 289-296.

[2] H. Huppertz and W. Schnick, Angew. Chem. Int. Edit. 35 (1996), 1983-1984.

[3] H. Huppertz and W. Schnick, Z. Anorg. Allg. Chem. 623 (1997), 212-217.

[4] H. Huppertz and W. Schnick, Acta Cryst. C 53 (1997), 1751-1753.

[5] H.A. Hoeppe, H. Trill, G. Kotzyba, B.D. Model, R. Poettgen and W. Schnick, Z. Anorg. Allg. Chem. 630 (2004), 224-228.

[6] W. Schnick, Int. J. Inorg. Mater. 3 (2001), 1267-1272.

[7] P.L. Wang, P.E. Werner, L. Gao, R.K. Harris and D.P. Thompson, J. Mater. Chem. 7 (1997), 2127-2130.

[8] E.A. Juarez-Arellano, A. Friedrich, K. Knorr, A. Lieb, B. Winkler, M. Amboage, M. Hanfland and W. Schnick, Acta Cryst. B 62 (2006), 424-430. 
[9] V. Milman, B. Winkler, J.A. White, C.J. Pickard, M.C. Payne, E.V. Akhmatskaya and R.H. Nobes, Int. J. Quant Chem 77:5 (2000), 895-910.

[10] C.J. Pickard, B. Winkler, R.K. Chen, M.C. Payne, M.H. Lee, J.S. Lin, J.A. White and V. Milman, Phys. Rev. Lett. 85 (2000), 5122-5125.

[11] V. Milman, B. Winkler and C.J. Pickard, J. Nucl. Mater. 322:2-3 (2003), 165-179.

[12] B. Winkler, C.J. Pickard and V. Milman, Chem. Phys. Lett. 362 (2002), 266-270.

[13] M. Mikami, K. Uheda and N. Kijima, Phys. Stat. Sol. (a) 203 (2006), 2705-2711.

[14] L. Bellaiche and D. Vanderbilt, Phys. Rev. B 61 (2000), 7877-7882.

[15] J.P. Perdew, K. Burke and M. Ernzerhof, Phys. Rev. Lett. 77 (1996), 3865-3868.

[16] H.J. Monkhorst and J.D. Pack, Phys. Rev. B 13 (1976), 5188-5192.

[17] S.J. Clark, M.D. Segall, C.J. Pickard, P.J. Hasnip, M.J. Probert, K. Refson and M.C. Payne, Z. Kristallogr. 220 (2005), 567-570.

[18] V. Vinograd, E.A. Juarez-Arellano, A. Lieb, K. Knorr, W. Schnick, J.D. Gale and B. Winkler, Z. Kristallogr. 222 (2007), 402-415.

[19] A. Lieb, Ph.D. thesis, Ludwig-Maximilians-Universitaet, Munich, 2006.

[20] R.D. Shannon, Acta Cryst. A32 (1976), 751-767.

[21] W. Schnick and H. Huppertz, Chem. Eur. J. 3 (1997), 679-683.

[22] R.J. Angel, Program EOS-FIT, version 4.2, 1998.

[23] B. Winkler, M. Hytha, M.C. Warren, V. Milman, J.D. Gale and J. Schreuer, Z. Kristallogr. 216 (2001), 67-70.

[24] R.J. Angel, in: R M Hazen and R T Downs (Eds), MSA Reviews in Mineralogy and Geochemistry. Vol. 41, 2000, p. 35.

\section{Figure Captions:}

Figure 1. The nitridosilicate structure, showing the labelling scheme used here.

Figure 2. The BaYb SiAlON crystal structure. $\mathrm{T}_{1}$ (black) and $\mathrm{T}_{2}$ (grey) tetrahedral-sites form star-like units. $=\mathrm{N}^{[4]}(1), \bigcirc=\mathrm{N}^{[2]}(2), \boldsymbol{O}=\mathrm{N}^{[2]}(3)$ (relative sizes adjusted for ease of visualization in greyscale).

Figure 3. Variation of the theoretical unit cell volume versus pressure of BaYb SiAlON. Equation-ofstate fits to experimental $(37 \mathrm{GPa})$ and theoretical data are represented by solid lines.

Figure 4. Theoretical and experimental volume-pressure data as a plot of the normalized pressure $F$ against the Eulerian strain $f$ of BaYb SiAlON.

Figure 5. Variation of the theoretical cell parameters, a (figure 6a) and c (figure 6b), versus pressure of BaYb SiAlON. Equation-of-state fits to experimental (37 GPa) and theoretical data are represented by solid lines. 
Table 1. Comparison of the experimentally determined [5] and predicted structures of the nitridosilicates. To simplify the comparison, the free $z$-coordinate of the $\mathrm{Yb}$ ion on the Wyckoff position $2 b,(2 / 31 / 30)$, was placed on $z=0.2362$ for all compounds, and the $z$-coordinates of all other positions were transferred correspondingly from the data given in the literature. $\mathrm{Sr}, \mathrm{Ba}, \mathrm{Eu}$ are on Wyckoff position $2 b$, and $\mathrm{Si}(2)$, $\mathrm{N}(2)$ and $\mathrm{N}(3)$ are on Wyckoff position $6 c$. All other atoms are on their special positions.

\begin{tabular}{|c|c|c|c|c|c|c|c|}
\hline & & \multicolumn{2}{|c|}{$\mathrm{BaYbSi}_{4} \mathrm{~N}_{7}$} & \multicolumn{2}{|c|}{$\mathrm{SrYbSi}_{4} \mathrm{~N}_{7}$} & \multicolumn{2}{|c|}{$\mathrm{EuYbSi}_{4} \mathrm{~N}_{7}$} \\
\hline & & exp. & theo. & exp. & theo. & exp. & theo. \\
\hline $\mathrm{a} / \AA$ & & $6.03119(8)$ & 6.075 & $5.9973(2)$ & 6.029 & $5.99408(6)$ & 6.020 \\
\hline $\mathrm{c} / \AA$ & & $9.8370(2)$ & 9.893 & $9.7814(3)$ & 9.833 & $9.7718(2)$ & 9.834 \\
\hline $\mathrm{a} / \mathrm{c}$ & & 0.613 & 0.614 & 0.613 & 0.613 & 0.613 & 0.612 \\
\hline $\mathrm{Ba}, \mathrm{Sr}, \mathrm{Eu}$ & $Z$ & $0.36264(3)$ & 0.3626 & $0.36511(5)$ & 0.3676 & $0.36534(5)$ & 0.3707 \\
\hline $\mathrm{Yb}$ & $Z$ & 0.2362 & 0.2355 & 0.2362 & 0.2361 & 0.2362 & 0.2368 \\
\hline $\mathrm{Si}(1)$ & $Z$ & $0.3138(2)$ & 0.3139 & $0.3124(2)$ & 0.3127 & $0.3120(2)$ & 0.3124 \\
\hline \multirow[t]{3}{*}{$\operatorname{Si}(2)$} & $x$ & $0.17430(7)$ & 0.1743 & $0.17366(9)$ & 0.1739 & $0.17359(7)$ & 0.1737 \\
\hline & $y$ & $0.34859(2)$ & 0.3486 & $0.3473(2)$ & 0.3478 & $0.34719(15)$ & 0.3475 \\
\hline & $Z$ & $0.0471(2)$ & 0.0462 & $0.04598(11)$ & 0.0463 & $0.04586(14)$ & 0.0461 \\
\hline $\mathrm{N}^{[4]}(1)$ & $Z$ & $0.1216(4)$ & 0.1236 & $0.1210(5)$ & 0.1226 & $0.1207(4)$ & 0.1225 \\
\hline \multirow[t]{3}{*}{$\mathrm{N}^{[2]}(2)$} & $x$ & $0.0226(5)$ & 0.0252 & $0.0212(3)$ & 0.0230 & $0.0204(3)$ & 0.0222 \\
\hline & $y$ & $0.5113(3)$ & 0.5126 & $0.5106(3)$ & 0.5115 & $0.5102(3)$ & 0.5111 \\
\hline & $Z$ & $0.0994(3)$ & 0.0987 & $0.0993(1)$ & 0.0982 & $0.0992(3)$ & 0.0973 \\
\hline \multirow[t]{3}{*}{$\mathrm{N}^{[2]}(3)$} & $x$ & $0.8466(3)$ & 0.8477 & $0.8465(3)$ & 0.8472 & $0.8463(3)$ & 0.8473 \\
\hline & $y$ & $-0.3068(5)$ & -0.3046 & $-0.3071(6)$ & -0.3056 & $-0.3074(6)$ & -0.3054 \\
\hline & $Z$ & $0.3730(3)$ & 0.3741 & $0.3717(3)$ & 0.3734 & $0.3713(2)$ & 0.3733 \\
\hline
\end{tabular}


Table 2. Predicted changes due to oxygen doping of $\mathrm{BaYbSi}_{4} \mathrm{~N}_{7}$ as calculated in the VCA. The unit cell volume is normalized to contain two formula units.

\begin{tabular}{|c|c|c|c|c|c|c|}
\hline \multirow{3}{*}{$\begin{array}{l}\mathrm{N}_{\text {total }}: \mathrm{O} \\
\mathrm{N}_{\text {site }}: \mathrm{O}\end{array}$} & \multicolumn{2}{|c|}{$\mathrm{N}(1)$} & \multicolumn{2}{|c|}{$\mathrm{N}(2)$} & \multicolumn{2}{|c|}{$\mathrm{N}(3)$} \\
\hline & $13: 1$ & $55: 1$ & $13: 1$ & $27: 1$ & $13: 1$ & $27: 1$ \\
\hline & $50: 50$ & $87.5: 12.5$ & $83.33: 16.67$ & $91.67: 8.33$ & $83.33: 16.67$ & $\begin{array}{c}91.76: 8.3 \\
3\end{array}$ \\
\hline $\mathrm{a} / \AA$ & 6.123 & 6.078 & 6.066 & 6.063 & 6.089 & 6.078 \\
\hline $\mathrm{c} / \AA$ & 9.853 & 9.879 & 9.915 & 9.897 & 9.840 & 9.867 \\
\hline $\mathrm{a} / \mathrm{c}$ & 0.621 & 0.615 & 0.612 & 0.613 & 0.619 & 0.616 \\
\hline $\mathrm{V} / \AA^{3}$ & 319.9 & 316.1 & 315.9 & 315.1 & 316.0 & 315.7 \\
\hline $\mathrm{d}(\mathrm{Si}-\mathrm{N} / \mathrm{O}) / \AA$ & 1.866 & 1.881 & 1.714 & 1.721 & 1.691 & 1.701 \\
\hline & 2.065 & 1.999 & & & 1.704 & 1.710 \\
\hline$(\mathrm{Si}-\mathrm{N} / \mathrm{O}-\mathrm{Si})$ & 105.3 & 106.0 & 114.9 & 114.3 & 119.6 & 118.8 \\
\hline angle / ${ }^{\circ}$ & 113.4 & 112.7 & & & & \\
\hline
\end{tabular}


Table 3. Comparison of experimental [19] and theoretical structure of BaYb SiAlON, space group $P 6_{3} m c$.

\begin{tabular}{|c|c|c|c|c|c|c|c|}
\hline & & & 0 GPa & 0 GPa & 0 GPa & $30 \mathrm{GPa}$ & $50 \mathrm{GPa}$ \\
\hline & $\begin{array}{l}\text { Wyckoff } \\
\text { position }\end{array}$ & & Experimental & Theoretical & $\begin{array}{c}\text { Difference } \\
(\%)\end{array}$ & Theoretical & Theoretical \\
\hline a & & $\AA$ & $6.0996(9)$ & 6.075 & 0.40 & 5.7943 & 5.6707 \\
\hline c & & $\AA$ & $9.923(2)$ & 9.9422 & -0.19 & 9.5007 & 9.3100 \\
\hline $\mathbf{V}$ & & $\AA$ & $319.74(9)$ & 317.76 & 0.62 & 276.24 & 259.27 \\
\hline Ba & $2 b$ & $\mathrm{z}$ & $0.25457(3)$ & 0.2544 & 0.07 & 0.2539 & 0.2538 \\
\hline $\mathbf{Y b}$ & $2 b$ & $\mathrm{z}$ & $0.627280(4)$ & 0.6277 & -0.07 & 0.6288 & 0.6292 \\
\hline \multirow[t]{2}{*}{ Si,Al (1) } & $2 a$ & $\mathrm{z}$ & $0.6998(2)$ & 0.7008 & 0.14 & 0.6978 & 0.6968 \\
\hline & & occ & $1 / 2 / 1 / 2$ & $1 / 2 / 1 / 2$ & - & $1 / 2 / 1 / 2$ & $1 / 2 / 1 / 2$ \\
\hline \multirow[t]{4}{*}{ Si,Al (2) } & $6 c$ & $\mathrm{x}$ & $0.66020(16)$ & 0.6582 & 0.02 & 0.6601 & 0.6608 \\
\hline & & $\mathrm{y}$ & $0.83010(8)$ & 0.8291 & 0.01 & 0.8301 & 0.8304 \\
\hline & & z & $0.94074(16)$ & 0.9393 & 0.08 & 0.9400 & 0.9402 \\
\hline & & occ & $1 / 2 / 1 / 2$ & $1 / 2 / 1 / 2$ & - & $1 / 2 / 1 / 2$ & $1 / 2 / 1 / 2$ \\
\hline$N^{[4]}(1)$ & $2 a$ & $\mathrm{z}$ & $0.0121(5)$ & 0.0115 & 5.22 & 0.0096 & 0.0092 \\
\hline \multirow[t]{4}{*}{$(\mathrm{O}, \mathrm{N})^{[2]}(2)$} & $6 c$ & $\mathrm{x}$ & $0.6918(6)$ & 0.6916 & 0.30 & 0.6869 & 0.6855 \\
\hline & & $\mathrm{y}$ & $0.8459(3)$ & 0.8458 & 0.01 & 0.8435 & 0.8427 \\
\hline & & $\mathrm{z}$ & $0.7619(3)$ & 0.7641 & -0.29 & 0.7621 & 0.7615 \\
\hline & & occ & $1 / 3 / 2 / 3$ & $1 / 3 / 2 / 3$ & - & $1 / 3 / 2 / 3$ & $1 / 3 / 2 / 3$ \\
\hline \multirow[t]{4}{*}{$(\mathrm{O}, \mathrm{N})^{[2]}(3)$} & $6 c$ & $\mathrm{x}$ & $0.4911(3)$ & 0.4888 & 0.47 & 0.4912 & 0.4922 \\
\hline & & $\mathrm{y}$ & $0.9823(5)$ & 0.9776 & 0.48 & 0.9824 & 0.9844 \\
\hline & & z & $0.9923(3)$ & 0.9918 & -0.05 & 0.9944 & 0.9951 \\
\hline & & occ & $1 / 3 / 2 / 3$ & $1 / 3 / 2 / 3$ & - & $1 / 3 / 2 / 3$ & $1 / 3 / 2 / 3$ \\
\hline
\end{tabular}


Table 4. Comparison of experimental [19] and theoretical bond and angles of BaYb-SiAlON. Space Group $\mathrm{P}_{3} m c$.

\begin{tabular}{|c|c|c|c|c|c|c|c|}
\hline \multicolumn{3}{|c|}{ Bonds / §̊ } & 0 GPa & 0 GPa & 0 GPa & 30 GPa & $50 \mathrm{GPa}$ \\
\hline & & & \multicolumn{5}{|c|}{ Difference } \\
\hline & & & Experimental & Theoretical & & Theoretical & Theoretical \\
\hline \multirow[t]{2}{*}{ Yb } & $(\mathrm{O}, \mathrm{N})^{[2]}(2)$ & $3 x$ & $2.285(3)$ & 2.3222 & -1.60 & 2.1803 & 2.1232 \\
\hline & $(\mathrm{O}, \mathrm{N})^{[2]}(3)$ & $3 x$ & $2.318(3)$ & 2.3083 & 0.42 & 2.175 & 2.1202 \\
\hline \multirow[t]{3}{*}{$\mathbf{B a}$} & $(\mathrm{O}, \mathrm{N})^{[2]}(2)$ & $6 x$ & $3.0536(5)$ & 3.0419 & 0.38 & 2.9000 & 2.8378 \\
\hline & $(\mathrm{O}, \mathrm{N})^{[2]}(3)$ & $3 x$ & $3.005(3)$ & 3.0122 & -0.24 & 2.885 & 2.825 \\
\hline & $(\mathrm{O}, \mathrm{N})^{[2]}(3)$ & $3 x$ & $3.087(3)$ & 3.0810 & 0.19 & 2.9306 & 2.8698 \\
\hline \multirow[t]{2}{*}{ Si,Al (1) } & $N^{[4]}(1)$ & $1 \mathrm{x}$ & $1.864(5)$ & 1.8821 & -0.97 & 1.7880 & 1.7466 \\
\hline & $(\mathrm{O}, \mathrm{N})^{[2]}(2)$ & $3 x$ & $1.740(3)$ & 1.7406 & -0.03 & 1.6853 & 1.6582 \\
\hline \multirow[t]{3}{*}{ Si,Al (2) } & $N^{[4]}(1)$ & $1 \mathrm{x}$ & $1.929(2)$ & 1.9359 & -0.36 & 1.829 & 1.785 \\
\hline & $(\mathrm{O}, \mathrm{N})^{[2]}(2)$ & $1 \mathrm{x}$ & $1.783(3)$ & 1.7502 & 1.87 & 1.6955 & 1.6679 \\
\hline & $(\mathbf{O}, \mathbf{N})^{[2]}(3)$ & $2 x$ & $1.775(2)$ & 1.7534 & 1.23 & 1.6936 & 1.6652 \\
\hline Si,Al (1) & Si,Al (2) & - & 3.135 & 2.976 & 5.34 & 2.864 & 2.812 \\
\hline
\end{tabular}

\begin{tabular}{|c|c|c|c|c|c|c|c|c|}
\hline \multicolumn{4}{|l|}{ Angles / ${ }^{\circ}$} & 0 GPa & $0 \mathrm{GPa}$ & $0 \mathrm{GPa}$ & $30 \mathrm{GPa}$ & $50 \mathrm{GPa}$ \\
\hline & & & & Experimental & Theoretical & $(\%)$ & Theoretical & Theoretical \\
\hline$(\mathrm{O}, \mathrm{N})^{[2]}(2)$ & $\mathrm{Yb}$ & $(\mathrm{O}, \mathrm{N})^{[2]}(3)$ & $6 x$ & $90.29(7)$ & 90.741 & -0.50 & 90.658 & 90.718 \\
\hline$(\mathrm{O}, \mathrm{N})^{[2]}(2)$ & $\mathrm{Yb}$ & $(\mathrm{O}, \mathrm{N})^{[2]}(3)$ & $3 x$ & $179.47(10)$ & 179.911 & -0.24 & 179.566 & 179.390 \\
\hline$(\mathrm{O}, \mathrm{N})^{[2]}(3)$ & $\mathrm{Yb}$ & $(\mathrm{O}, \mathrm{N})^{[2]}(3)$ & $3 x$ & $89.33(11)$ & 89.201 & 0.14 & 89.032 & 88.846 \\
\hline$(\mathrm{O}, \mathrm{N})^{[2]}(2)$ & $\mathrm{Yb}$ & $(\mathrm{O}, \mathrm{N})^{[2]}(2)$ & $3 x$ & $90.09(10)$ & 89.317 & 0.86 & 89.650 & 89.715 \\
\hline$N^{[4]}(1)$ & Si,Al (1) & $(\mathrm{O}, \mathrm{N})^{[2]}(2)$ & $3 x$ & $110.72(11)$ & 111.213 & -0.44 & 111.253 & 111.323 \\
\hline$(\mathrm{O}, \mathrm{N})^{[2]}(2)$ & Si,Al (1) & $(\mathrm{O}, \mathrm{N})^{[2]}(2)$ & $3 x$ & $108.19(12)$ & 107.674 & 0.48 & 107.632 & 107.557 \\
\hline$N^{[4]}(1)$ & Si,Al (2) & $(\mathrm{O}, \mathrm{N})^{[2]}(3)$ & $2 x$ & $111.19(11)$ & 111.214 & -0.45 & 110.878 & 110.707 \\
\hline$N^{[4]}(1)$ & Si,Al (2) & $(\mathrm{O}, \mathrm{N})^{[2]}(2)$ & $1 \mathrm{x}$ & $106.14(17)$ & 106.021 & 0.11 & 106.631 & 106.912 \\
\hline$(\mathrm{O}, \mathrm{N})^{[2]}(2)$ & Si,Al (2) & $(0, N)^{[2]}(3)$ & $2 x$ & $109.70(12)$ & 110.308 & -0.55 & 110.122 & 110.013 \\
\hline$(\mathrm{O}, \mathrm{N})^{[2]}(3)$ & Si,Al (2) & $(\mathrm{O}, \mathrm{N})^{[2]}(3)$ & $1 x$ & $108.90(19)$ & 107.796 & 1.02 & 108.222 & 108.487 \\
\hline & $(\mathrm{O}, \mathrm{N})^{[2]}$ & & & & & & & \\
\hline Si,Al (1) & (2) & Si,Al (2) & - & 111.529 & 116.966 & -4.87 & 115.815 & 115.469 \\
\hline
\end{tabular}


Table 5. Parameters fitted from third order Birch-Murnaghan equations of state of BaYb SiAlON.

\begin{tabular}{lrrr}
\hline & Exp. [8] & \multicolumn{1}{c}{ DFT } & Diff. \% \\
\hline $\boldsymbol{B}_{\mathbf{0}} / \mathbf{G P a}$ & $168(2)$ & $158(1)$ & -5.95 \\
$\boldsymbol{B}^{\prime}$ & $4.7(2)$ & $4.3(1)$ & -8.5 \\
\hline $\boldsymbol{B}_{\mathbf{0 a}} / \mathbf{G P a}$ & $167(4)$ & $157(1)$ & -5.99 \\
$\boldsymbol{B}_{\boldsymbol{a}}$ & $4.7(4)$ & $4.2(1)$ & -10.64 \\
\hline $\boldsymbol{B}_{\mathbf{0}} / \mathbf{G P a}$ & $166(5)$ & $161(1)$ & -3.01 \\
$\boldsymbol{B}_{\boldsymbol{c}}{ }_{\boldsymbol{c}}$ & $4.8(5)$ & $4.6(1)$ & -4.17 \\
\hline
\end{tabular}


Fig. 1

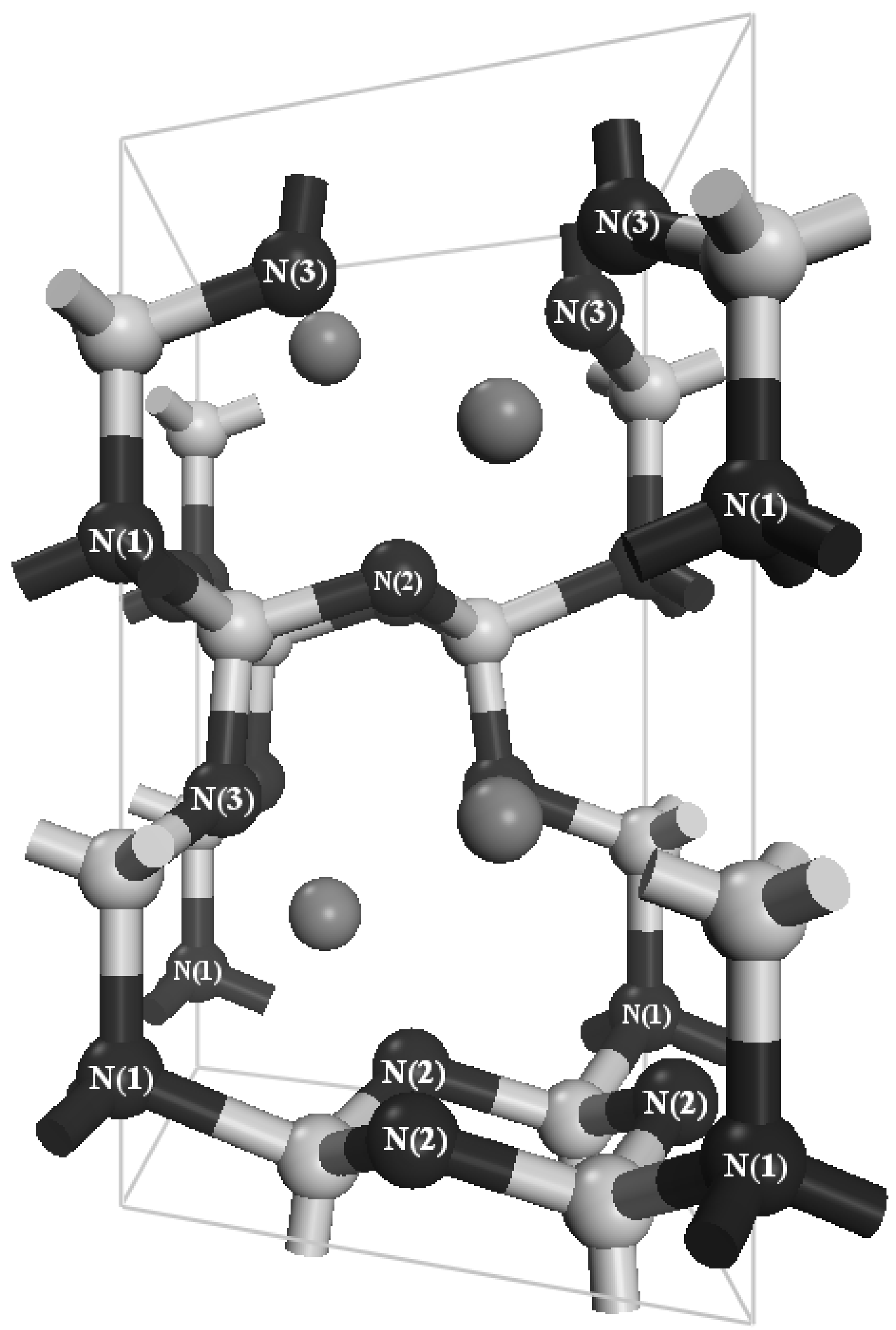


Fig. 2

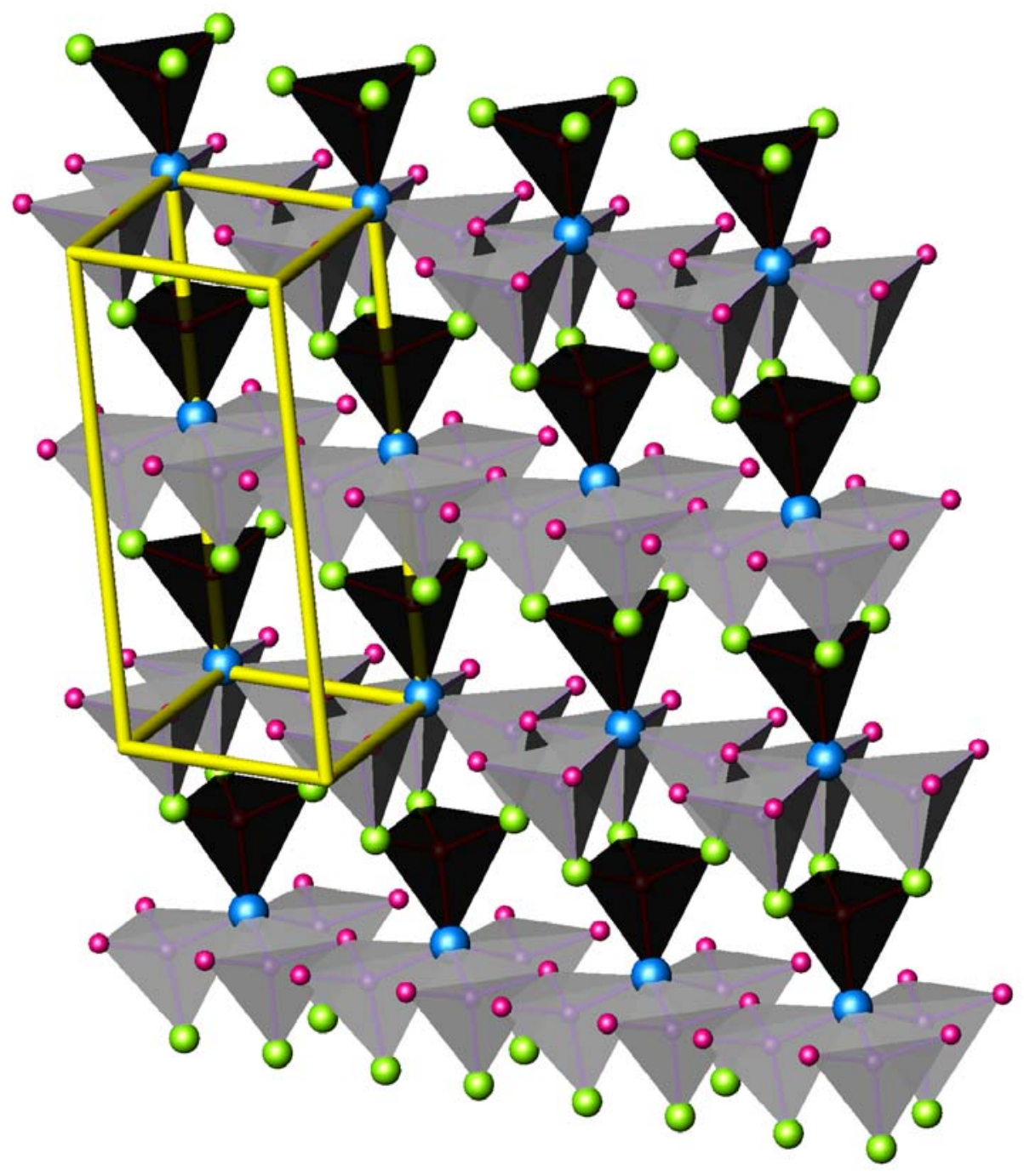


Fig. 3

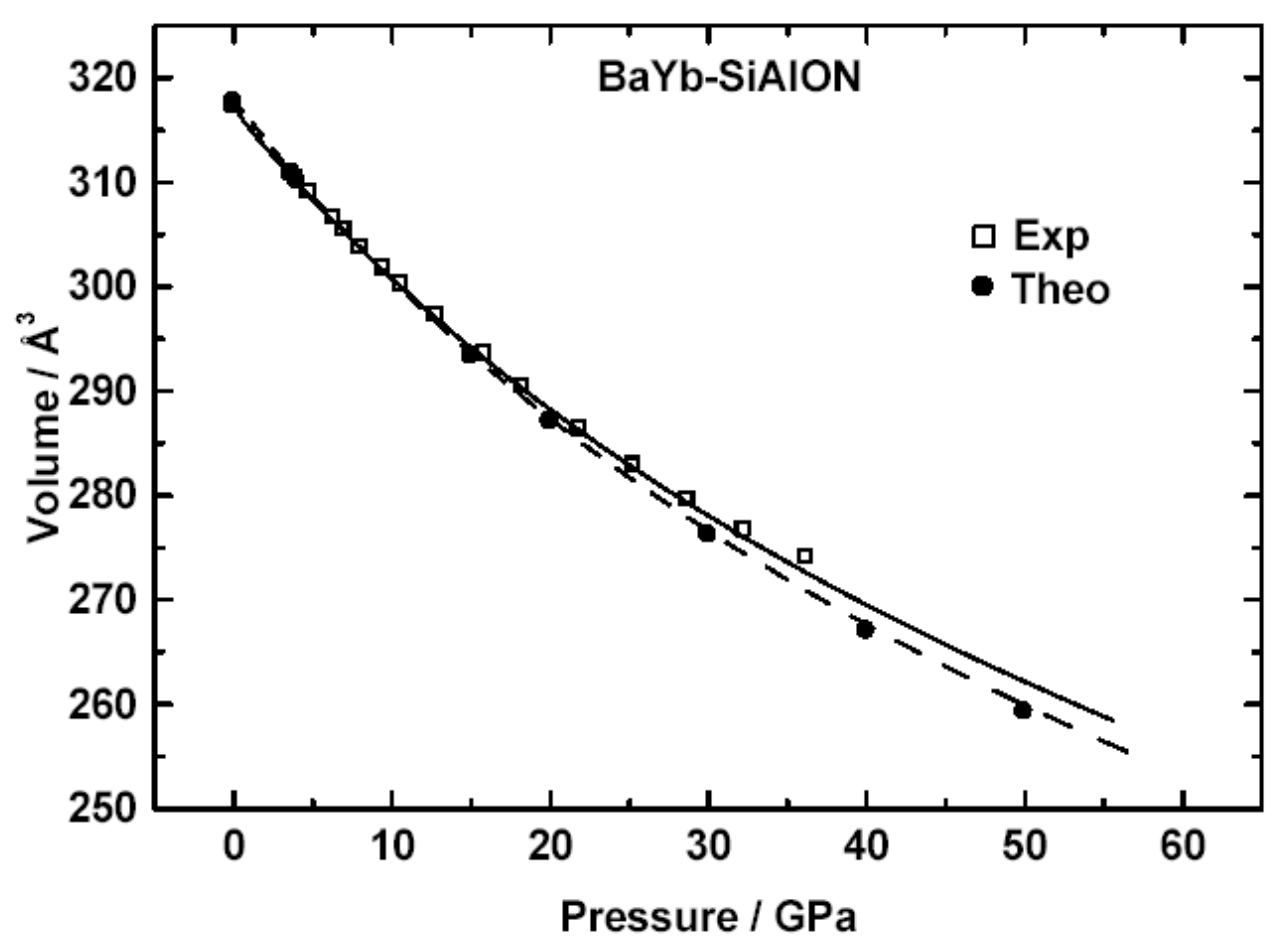


Fig. 4

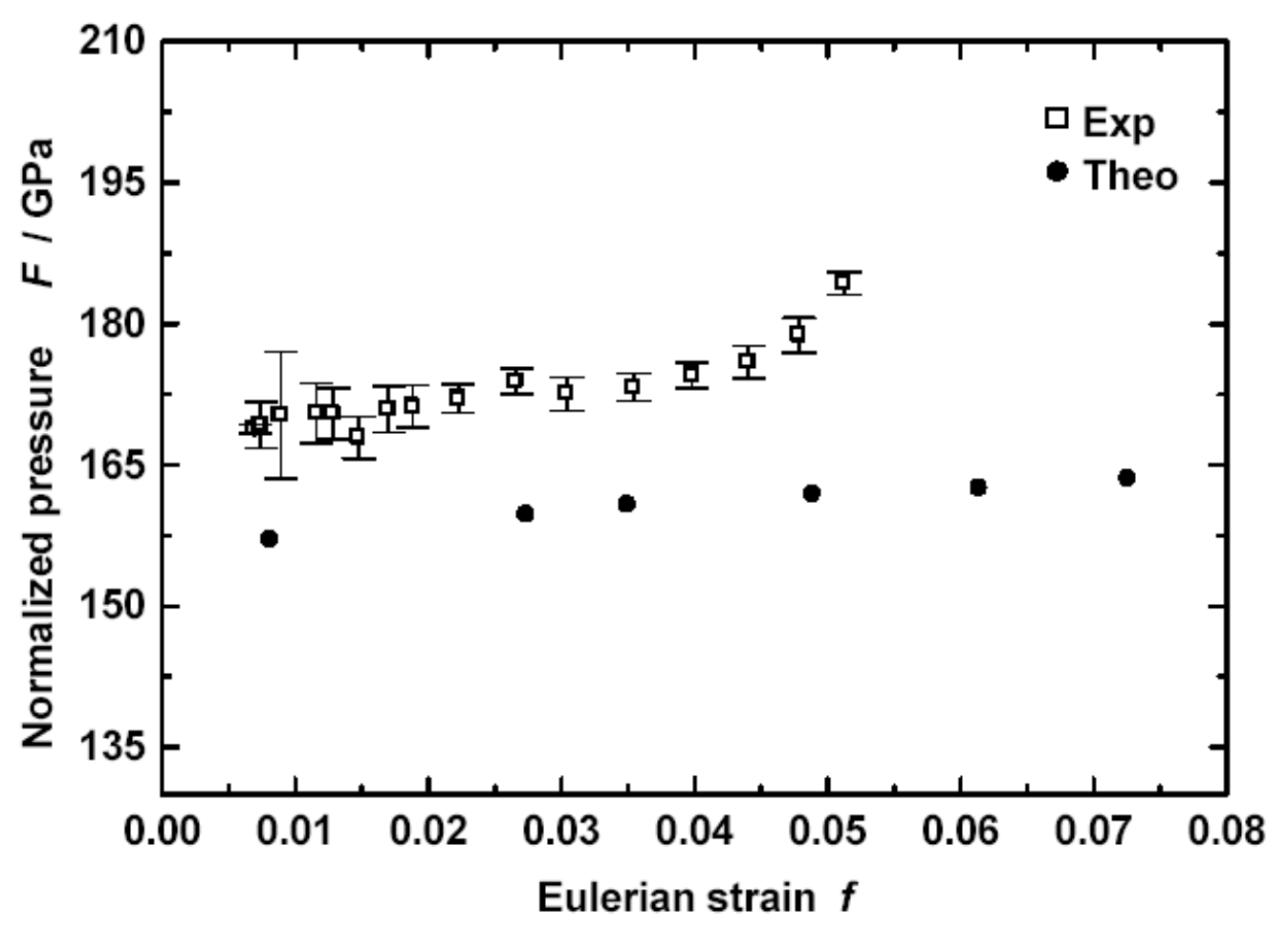


Fig. $5 \mathrm{a}$

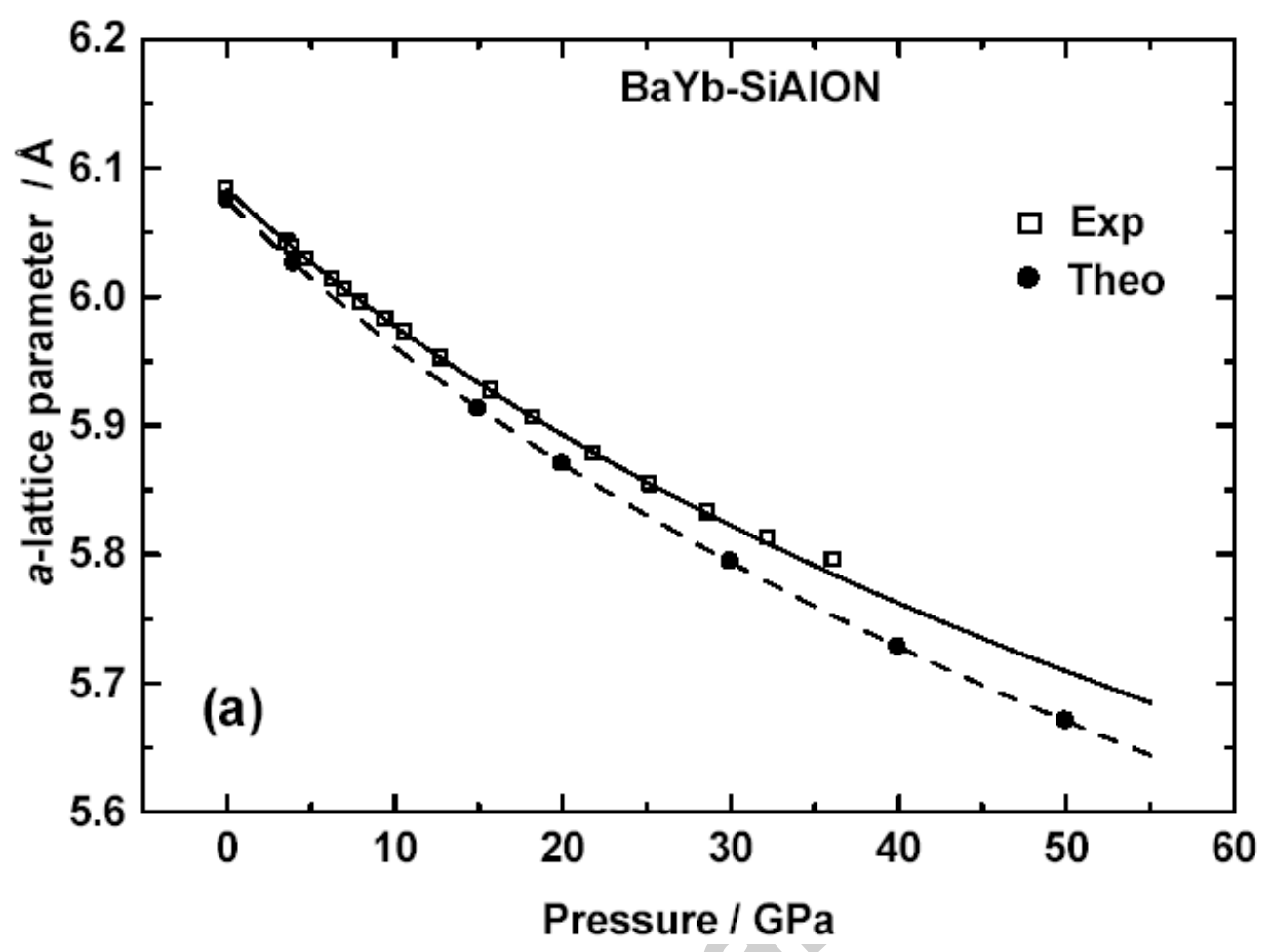


Fig. 5 b

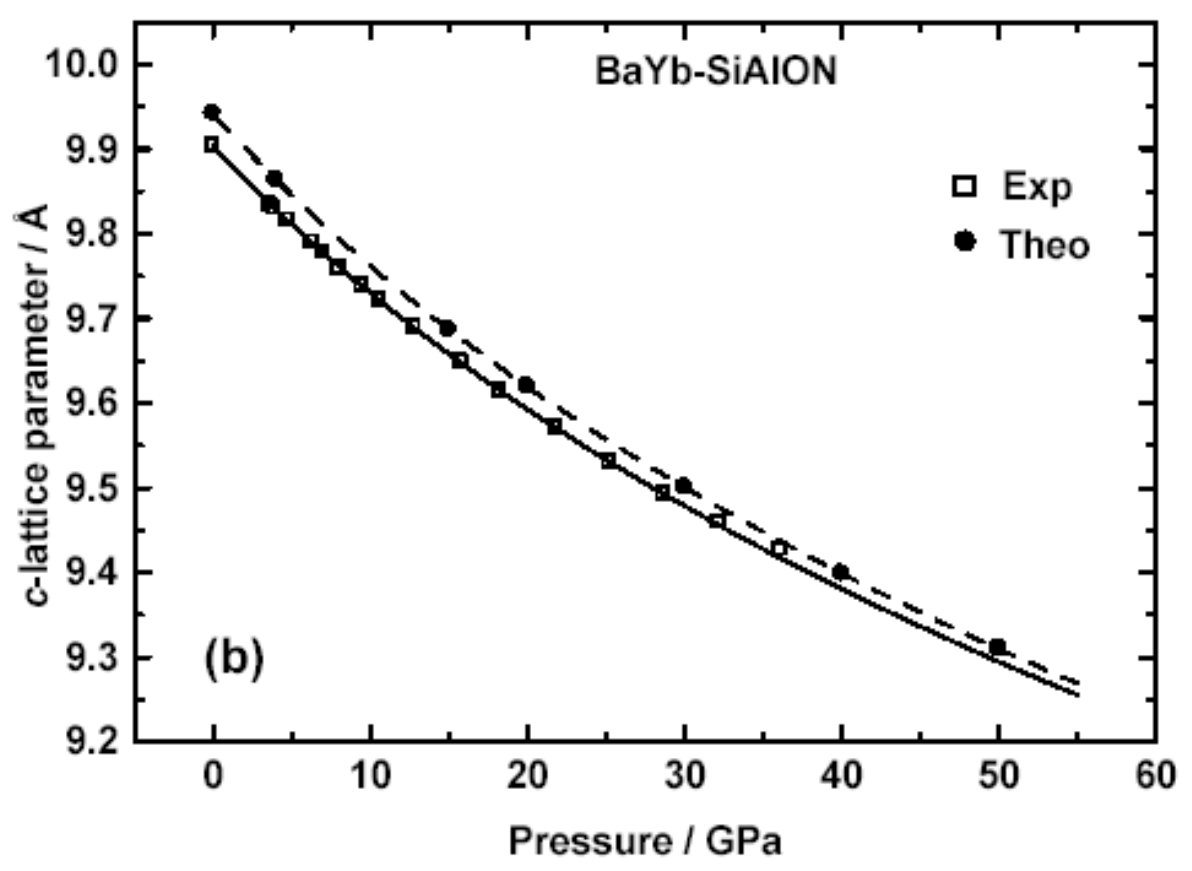

